IRSH 64 (2019), pp. I $25-147$ doi:10.1017/S002085901900005 I

(C) 2019 Internationaal Instituut voor Sociale Geschiedenis

\title{
Securing Trade: The Military Labor of the British Occupation of Manila, I762-1 $764^{*}$
}

\author{
Megan C. Thomas \\ Department of Politics, University of California, Santa Cruz \\ I 56 High St., Santa Cruz, CA 95060, USA \\ E-mail:mcthomas@ucsc.edu
}

\begin{abstract}
Military labor played a key role in conquering and preserving ports as nodes in trading networks. This article treats the military labor of the British occupation of Manila from I 762 to I 764 , during the Seven Years War. It examines the motley crew that formed the British forces, exploring British categories of military laborers sent from Madras. The particular combination of forces composed for this expedition had more to do with the East India Company's concerns in Madras than with what was thought to be needed to take and hold Manila. These military laborers were sometimes unruly, insisting on better pay, and deserting when it was not forthcoming. The story of the British occupation of Manila highlights how ideas about desertion traveled along with military laborers from one port city to another in the Indian Ocean world, and what happened when they did.
\end{abstract}

\section{INTRODUCTION}

In 1762 , a few days before leaving the British East India Company's port of Madras (now Chennai) on a military expedition to seize the Spanish port of Manila, the British commander Brigadier General William Draper wrote to the Secretary at War in London complaining that most of his men were

a composition of deserters of all nations who I take with me more to ease the fears and apprehensions of the people at Madrass, than from any service I can expect from them; as, perhaps, I shall only carry recruits to the enemy, but I

\footnotetext{
* I would like to thank the editors for inviting me to contribute to this Special Issue, and especially Pernille Røge and Pepijn Brandon for guiding revisions; workshop participants, Catherine Jones, and Christina Welsch for crucial comments on earlier drafts; Christina Welsch for generously sharing with me her knowledge of and work on the Madras military of this period; and Bettina Ng'weno for sharing with me her knowledge about the histories of Africans in India.
} 
have no choice. Those or none; such banditti were never assembled since the time of Spartacus. ${ }^{\mathrm{I}}$

Draper likely worried sincerely about the quality of his personnel, and also sought to lower his superiors' expectations, to shield himself from blame should the endeavor fail. But his words also reflect truths about military labor's composition in South Asia in this period. It was composed of a motley crew, managed through categories that corresponded less to how the men identified themselves than to how they were treated by their superiors: the work for which they were deployed, the conditions under which they labored, and the pay they would receive.

This motley military labor produced global commerce. Along with diplomacy, war aimed to produce the access and security on which the profits of long-distance trade depended. Imperial expansion required a great deal of military labor to secure markets and access to raw materials, and to create the conditions that yielded workers available perform the labor of extraction and production. As Peter Way has argued, because war is central to capitalism's emergence, "it is necessary to reconceptualize soldiers as war workers, indeed, as transnational laborers whose martial toil around the globe proved integral to the development of international capitalism". ${ }^{2}$ Much of that martial toil was in port cities; commercial empires depended on the work that secured access to and control over a port's trade. As key nodes in emerging global trade, port cities were critical sites of military labor, and targets in wars of imperial rivalry.

Military labor, therefore, was a significant part of port cities' labor. Often, like other laborers in port cities, these military workers came from elsewhere, having been made mobile by processes of dispossession and accumulation. In port cities, military labor was itself a sort of commodity of more or less trained and disciplined bodies, moving in and out of port cities along with other products of emerging imperial commercial trade. So, while military labor often worked to secure port cities, port cities were also points at which the motley military crew was gathered, mustered, garrisoned, trained, disciplined, paid (or not), and sent into the field. The port city was also a place where military laborers sometimes disobeyed, mutinied, or deserted.

As Way's work has shown of military labor in the Atlantic world, in the Indian Ocean armies drew on labor that had traveled great distances in coercive if not technically unfree conditions. The Atlantic context, however, has no real counterpart to the British East India Company's own military. The

I. The UK National Archives [hereafter, TNA]: War Office records [hereafter, WO] I/I 39, pp. 355-356. Transcribed in Nicholas Cushner (ed.), Documents Illustrating the British Conquest of Manila, $1762-1763$ (London, I97I), p. 34.

2. Peter Way, “Black Service ... White Money': The Peculiar Institution of Military Labor in the British Army during the Seven Years' War", in Leon Fink (ed.), Workers Across the Americas: The Transnational Turn in Labor History (Oxford, 201 I), pp. 57-80, 62. 

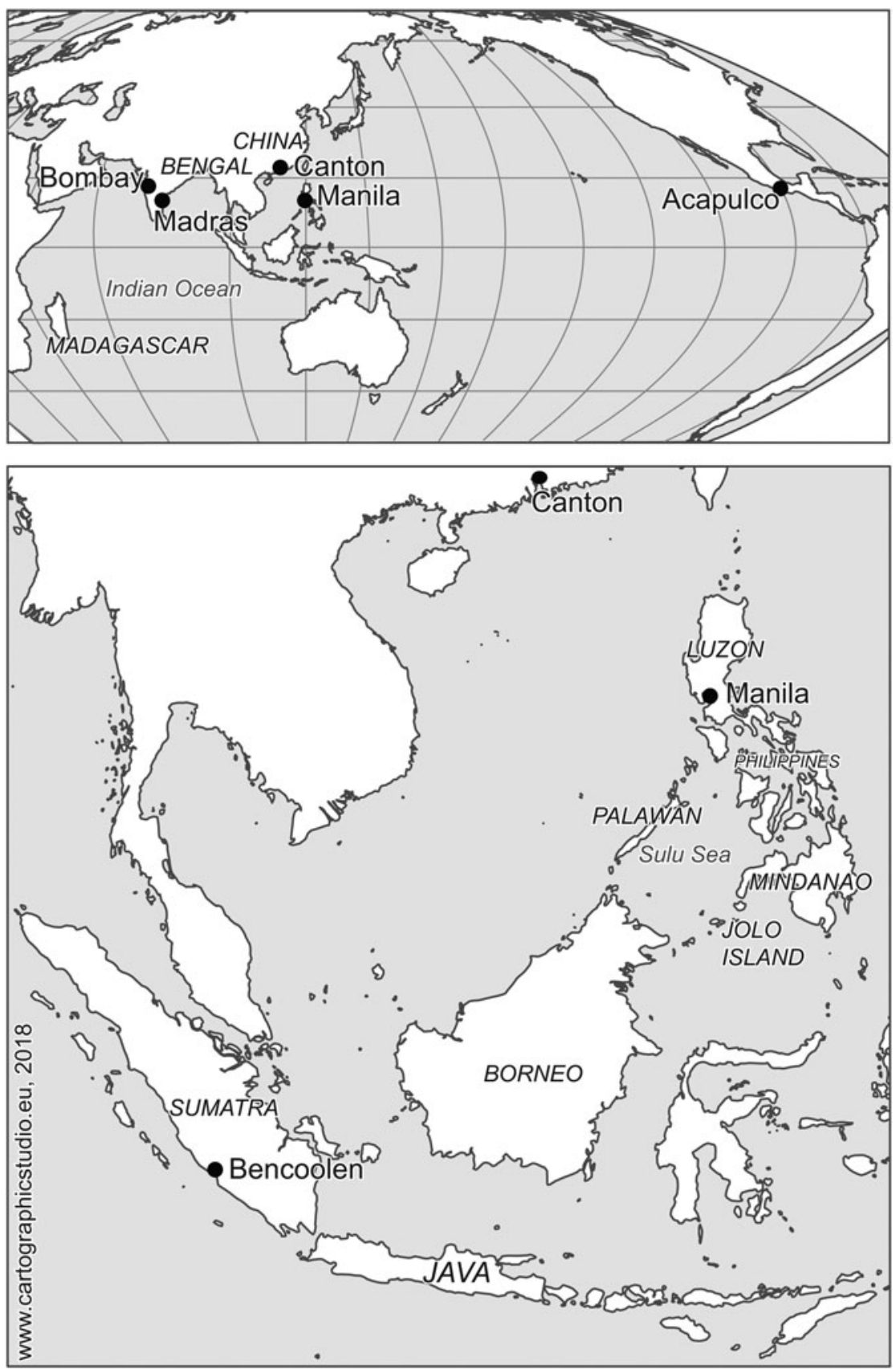

Figure I. Island Southeast Asia (East Indies). 
Company's military grew significantly in this period, increasingly incorporating a long-mobile Indian soldiery. ${ }^{3}$ The Company competed for that military labor with Indian states and other European companies alike. The complex alliances and enmities amongst Indian states and European trading companies significantly shaped where the Company's military labor came from, but also where else it might go.

While desertion troubled militaries in the Atlantic world too, desertion was a particular problem, but also an opportunity for militaries in South Asia in this time. ${ }^{4}$ The Company worried about its own troops deserting, but also actively recruited deserters of other forces into its own ranks. Its military, then, was composed from those it gathered from amongst its allies as well as from its enemies, and, as Christina Welsh has shown, soldiers in South Asia (both Indian and European) navigated the paths of opportunity they found in the military labor market as it existed amongst the tensions and ties between European trading companies and Indian states and rulers. ${ }^{5}$ Welsch has also noted that the Company was unusually lenient toward its own deserters in this era, another indication of how Company commanders tried to manage the opportunities and liabilities of desertion. ${ }^{6}$

This article deals with the military labor of the British occupation of Manila from 1762 to 1764 , during the Seven Years War, exploring a number of aspects of the composition and deployment of military labor in this moment of imperial expansion. It examines the composition of British forces, explores the categories of military laborers that powered British expansion in the Indian Ocean world, and explains why the particular combination of forces composed for this expedition had more to do with pressures in Madras than with what was thought to be needed to take and hold Manila. It also considers how those military laborers took actions that confounded their commanders: insisting on better pay, and deserting when it was not forthcoming. As we will see, when the motley forces of the British brought with them from Madras to Manila expectations about and experiences of desertion, their commanders struggled to respond effectively to the mobility of military labor in the environment of Manila. The story of the British

3. Dirk Kolff, Naukar, Rajput and Sepoy: The Ethnohistory of the Military Labour Market in Hindustan, I450-1850 (Cambridge, I990); Christina Welsch, "The Sons of Mars and the Heirs of Rustam: Military Ideology, Ambition, and Rebellion in South India (I746-I 8 I 2)” (Ph.D. dissertation, Princeton University, 2017), especially ch. I.

4. Matthias van Rossum and Jeannette Kamp (eds), Desertion in the Early Modern World: A Comparative History (London, 2016), especially ch. 8: Matthias van Rossum, "From Contracts to Labour Camps? Desertion and Control in South Asia", pp. I87-202, I87, I88, 194; Welsch, "Sons of Mars", especially ch. 3.

5. Welsch, "Sons of Mars".

6. Ibid., p. I60; cf. Pepijn Brandon, "The Privilege of Using Their Legs': Leaving the Dutch Army in the Eighteenth Century", in Van Rossum and Kamp, Desertion in the Early Modern World, pp. 73-93, 83; Van Rossum “From Contracts to Labour Camps?”, p. I95. 
occupation of Manila, then, shows what could happen when military laborers were sent across the Indian Ocean from one port city to conquer another.

\section{BRITISH PLANS FOR MANILA'S OCCUPATION}

Manila played an important role in eighteenth-century global trade. It was on the western edge of the Spanish trade across the Pacific, part of southern Chinese trading networks across the South China Sea, and on the easternmost limb of British networks in the Indian Ocean. For the Spanish, Manila was a crucial node in the galleon trade linking Spain and the Americas with China across the Pacific. At Manila, American silver was exchanged for luxury goods from China, which were shipped to the Americas and eventually to Spain. ${ }^{7}$ From China's southern coast, merchants, artisans, and seafarers knew Manila as part of the South China Sea trading networks. Those networks were essential for the "Spanish" city; Chinese junks brought porcelains, silks, and other goods to Manila, and the commerce of the city was more Chinese than Spanish. ${ }^{8}$ Periodically, the Spanish administration wrought violence on the Chinese in Manila, and in 1755 non-Christian Chinese were expelled; hundreds had become baptized in order to stay. ${ }^{9}$ At the time of the British occupation, Manila and its surrounding suburbs and towns probably had a population of between 70,000 and $100,000 .^{10}$

The plan to occupy Manila was in part a continuation of the East India Company's China trade. Manila was on the eastern periphery of its Indian Ocean trade, and a crucial source of silver, valued in Canton unlike British and Indian goods. Though technically barred from trading in Manila, British merchants regularly circumvented the ban, trading for silver that in Canton bought the luxury goods so valued in Europe. ${ }^{\text {I }}$ Seeking an alternative to silver, the Company had, for some time, aspired to establish a base in the realm of the Sultan of Sulu (which extended north to Palawan, west to Borneo, and east to Mindanao), where they hoped to exchange British and

7. William Lytle Schurz, The Manila Galleon (New York, I939).

8. O.D. Corpuz, The Roots of the Filipino Nation, 2 vols (Quezon City, 2005 [1989]), I, pp. 358-358; Arturo Giraldez, The Age of Trade: The Manila Galleons and the Dawn of the Global Economy (Lanham, MD, 20I5), pp. I60-16I; T'ien Ju-K'ang, “The Chinese Junk Trade: Merchants, Entrepreneurs, and Coolies, I600-1850", in Klaus Friedland (ed.), Maritime Aspects of Migration (Cologne and Vienna, 1989), pp. $38 \mathrm{I}-389$.

9. Corpuz, Roots of the Filipino Nation, pp. 306-307.

Io. This estimate is drawn from Madras Presidency Records Office, Records of Fort St. George, Manilha Consultations, 8 vols (Madras, 1940-1946), III, p. I2, as well as Linda Newson, Conquest and Pestilence in the Early Spanish Philippines (Quezon City, 201 I), pp. 42-43, 309, 3II, 3I 2, 383 .

I I. Serafin D. Quiason, English "Country Trade" with the Philippines, I644-I765 (Quezon City, 1966). 
Indian goods for regional forest and sea products that were highly valued in Canton. When Spain belatedly joined the French side of the war against Britain, Manila became an enemy target, and its occupation an opportunity for the Company to pursue its trading base plans. The Company also hoped to seize silver arriving in Manila from the Acapulco galleon, to fund investments in the upcoming trade season at Canton. For the Crown, occupying Manila had strategic value as a bargaining chip to be used in negotiations with Spain and France at the war's end. The British occupation of Manila, then, was envisioned not so much to secure that port's trade for Britain, but instead to secure British trade with Canton.

Manila was also thought to be an economical target, requiring only a relatively small investment of British troops and capitalizing on the proximate location of relatively inexpensive South Asian military labor based in the Company's presidency of Madras on the Coromandel coast. The institutional processes and pressures that came to bear on these plans, however, would shape the force in ways not originally envisaged. As the planning process unfolded, we see much more concern about the Company's position in India than about what would actually be required to take and hold Manila.

Plans were first drawn up in London but significantly revised in Madras in ways that reflect the Company's strong priorities for maintaining security along the Coromandel coast of the Carnatic, and British conviction that European troops were more valuable than Indian troops. Initial plans hatched in London called for about 2,000 infantrymen, accompanied by "a moderate train of artillery", officers, and an engineer. ${ }^{\mathrm{I}}$ Of the infantrymen, between seventy and eighty per cent were to be Europeans, and between twenty and thirty per cent would be "sepoys", South Asian infantrymen trained in European styles of warfare but paid just over half what European infantry were. ${ }^{\mathrm{I}}$ Because of company concerns that security on the Coromandel coast might be compromised by sending so large a force, ${ }^{\mathrm{I}}$ the commander of the expedition, William Draper, was to make the final determination about the composition of forces in consultation with Company officials in Madras. ${ }^{15}$ In Madras, the proposal became more ambitious than the original London plans in terms of overall numbers, increasing the total by forty per cent (from 2,000 to 2,805 ), mostly by quadrupling the number of sepoys (from 500 to 2,000), but also by adding the labor of eighty-four "Coffreys", about whom we will hear more below. But the plan had become more conservative in terms of using European

I 2. Cushner, Documents Illustrating the British Conquest of Manila, p. I 3 .

13. Ibid:; [Madras Army], Orders, Rules, and Regulations to be Observed Respecting the Troops on the Coast of Choromandel (s.1., I766), pp. 9, 21.

I4. Cushner, Documents Illustrating the British Conquest of Manila, p. I 5.

I s. Ibid., p. I9. 
troops, halving their numbers. ${ }^{16}$ The council was concerned that even though the plan drastically scaled back the number of European troops to be sent, British forces in Madras would be dangerously depleted, and they approved the plan only because they hoped the troops would return before their absence would pose a danger. ${ }^{17}$

But there were also some European Company troops whose presence in Madras worried the Company: French deserters. The French deserters were men who had been serving in the French military in India; in their struggles against the French, the British had decided in 1758 to form companies of French deserters within British ranks, "to encourage desertion among the enemy's troops". ${ }^{18}$ The numbers of French deserters had swollen during the brutal British siege of the French garrison at Pondicherry in 1760 , when many starving soldiers defected. After this, the number of French prisoners and deserters in Madras was a source of worry for the Company. ${ }^{19}$ The British feared that the defeated French might regroup against them, whether under their own banner or that of another hostile power. ${ }^{2 \circ}$ French soldiers, whether deserters or prisoners, needed to be kept alive but harmless, and, preferably, they would be sent away. Several months before the Manila expedition left Madras, the Military Council there was "desirous of letting no opportunity slip of getting transported to Europe as many French Prisoners as possible", proposing to send them by way of Bombay or Canton. ${ }^{21}$ In the midst of this dilemma, the Manila expedition offered an opportunity: transporting them to distant Manila seemed a reasonable way to prevent them from rejoining French forces in the Carnatic, and, at the same time, doing so allowed the Company to contribute troops that counted as "European" without actually sending troops that it valued.

Company officials likely doubted the value of the French deserters as soldiers, for reasons that did not make it into the record of these deliberations. Some French deserters were serial deserters: having deserted from French forces in Europe, they signed up for Indies service in exchange for amnesty, and so would already have deserted at least twice (in Europe and in India) before being sent to Manila. ${ }^{22}$ To complicate matters, many French

16. British Library (BL): India Office Records (IOR)/P/25I/48 bk. 2, pp. 102-105. A copy is transcribed, with one apparent minor error, in Cushner, Documents Illustrating the British Conquest of Manila, pp. 27-29.

I7. Ibid.

I8. W.J. Wilson, History of the Madras Army, s vols (Madras, I882-I889), I, p. I 22.

19. Ibid., pp. I73-174.

20. Many French deserters ended up in the forces of Haider Ali, the later commander of Mysore. Maya Jasanoff, Edge of Empire: Lives, Culture, and Conquest in the East, I750-1850 (New York, 2005), pp. I $54-155$.

21. BL: IOR/P/25I/48 bk. I, p. 98 (quote, and Bombay), and bk. 2, pp. $45-46$ (Canton).

22. John Malcom, The Life of Robert, Lord Clive: Collected from the Family Papers, 3 vols (London, I836), I, pp. 368-369. 
European infantrymen were not from France, but were Catholics from elsewhere in Europe. Some were, for example, Swiss mercenaries, but others were Britain's Catholics whose loyalty to the Crown was suspect: Scottish Jacobites, i.e. Catholics or supporters of a Stuart monarch, and Irish Catholics. ${ }^{23}$ No one in Madras considered - or more likely, no one wanted those thoughts committed to the record - that the French deserters' Catholicism might become a liability if they were supposed to be fighting Catholics in Manila.

The commanders had other reservations and complaints. Most notably, Company officials worried that "it may be a difficult matter to find the Number of Seapoys [...] required $[2,000]$ willing to go". ${ }^{24}$ Their solution was to offer them significant advance pay, as well as allowing their families to receive their pay directly from the company at Madras, while the men themselves were on the expedition. ${ }^{25}$ These enticements were, however, insufficient. Just before leaving Madras, Draper wrote that he expected only about a quarter of the sepoys that he had been promised, a decrease that he attributed to religious rather than financial concerns: "their averseness to sea voyage [thought to be connected with caste], the difference of religion $\&$ particular methods of diet". ${ }^{26}$ In the end, only 600 sepoys embarked for Manila, and they were not all the experienced "disciplined" sepoys initially imagined; instead, as Draper later complained, half of them were "Raw \& new raised". ${ }^{27}$

In sum, the British in Madras planned for the occupation with their attention focused more on Madras than on Manila. The Crown and Company each stood to gain from a successful venture at Manila, but they stood to gain different things, and for the Company the attendant risks at Madras were greater. The Company felt pressures at Madras to cut down on its overall commitment of troops to the expedition, and also to compose those troops strategically, seeking to eliminate the threat posed by the presence of many French deserters in their own ranks by sending them off to Manila. Though the Company hoped their troops - particularly their British troops - would return from Manila relatively quickly, they also maneuvered to send troops whose absence they would not particularly lament. ${ }^{28}$ Thus, Draper was absolutely correct when he wrote that he

23. Jasanoff, Edge of Empire, p. 26.

24. BL: IOR/P/25I/48 bk. 2, pp. II $8-$ I 23 .

25. Ibid. Family benefits were important in the Madras military in particular, as Christina Welsch has explored in “'An Indulgence Which Can Never Be Denied Them': The Question of Family Benefits in the East India Company's Madras Army, I746-I8I2”, paper presented at the Association for Asian Studies annual meeting, Chicago, 2015.

26. Cushner, Documents Illustrating the British Conquest of Manila, p. 35.

27. Ibid., pp. I3-I4 (“disciplined”); TNA: WO/I/I 39 ("raw \& new raised”).

28. Cushner, Documents Illustrating the British Conquest of Manila, pp. 40-42. 
thought the expedition's troops were chosen "more to ease the fears and apprehensions of the people at Madrass, than from any service I can expect from them".

\section{THE COMPOSITION OF BRITISH MILITARY LABOR}

Overall, British land forces in the Manila operation were a crew cobbled together by economic and political forces in India and beyond. Who, in the end, comprised that crew? Sources vary, but the most comprehensive single account enumerates 1,478 total rank-and-file land troops, composed of royal infantrymen (57I), sepoys (468), “The Honorable Company's Troops" (3 10), royal artillerymen (57), "the Nabob's Irregulars" (43), and Company artillerymen (29). ${ }^{29}$ They were accompanied by 335 officers, for a total of $\mathrm{I}_{1} 8 \mathrm{I}_{3}$ land forces. British royal naval forces were also landed as part of the initial attack on Manila: 632 private seamen (with 47 officers) and 274 Marines (with 64 officers), for a total of $\mathrm{I}, 0 \mathrm{I} 7 \mathrm{members}$ of the sea forces landed. ${ }^{\circ}$

Of the land troops, 600 were rank-and-file "sepoys" and their South Asian officers. ${ }^{3 \mathrm{I}}$ In addition to being paid less that European troops, sepoys served in separate units, and while they had South Asian officers, they were always commanded at the highest levels by Europeans. ${ }^{32}$ Sepoys were used in the South Asian militaries of European companies and Indian rulers alike, but the British and French increasingly relied on them during the Carnatic Wars. ${ }^{33}$ While on campaign, unlike European infantrymen who were provisioned, sepoys had to buy their own food, for which they were allotted a subsistence cash allowance called a batta. Sepoys, therefore, were "absolutely

29. Unless otherwise indicated, these numbers are derived from troop returns in BL: IOR H/77, pp. $4^{8-49}$, transcribed imperfectly in Cushner, Documents Illustrating the British Conquest of Manila, p. 57 .

30. "An Account of the Number of Seamen and Marines Landed from His Majesty's Squadron [...]", in Cushner, Documents Illustrating the British Conquest of Manila, p. 56; the same numbers are given in the map "Draught of the Great Bay of Manilla and Harbour of Cavita [...] Surveyed \& Drawn [...] by William Nichelson”, 1764. These numbers exclude those on the ships but not landed.

3 I. As was typical of Madras Company returns at the time, "European" troops are listed separately from "sepoy" troops. BL: IOR H/77, pp. $48-49$.

32. Much of what we know about sepoys comes from later years, when the number of sepoys shot up and systems for recruitment, pay, and discipline became centralized and standardized, and from which more records survive. An important corrective is Welsch, "Sons of Mars", especially ch. I.

33. Jasanoff, Edge of Empire, pp. 90-92; P.J. Marshall, "Western Arms in Maritime Asia in the Early Phases of Expansion”, Modern Asian Studies, I4:I (1980), pp. I3-28, 26, citing G.J. Bryant, "The East India Company and its Army I600-1778" (Ph.D. dissertation, University of London, 1975). 
dependent on their pay and ready to mutiny or desert if payment was seriously delayed". ${ }^{34}$ The Manila operation may have been the first time that sepoys had been deployed overseas, though it would not be the last. We have already heard Draper blame the sepoys' reluctance to go to Manila on their "averseness to sea voyage", but material concerns were at least as pressing. Some of these sepoys had likely previously been on campaign in Bengal, while others, as Draper complained, were inexperienced and on their first campaign. ${ }^{35}$ Most of these sepoys had family near Madras, though as part of the itinerant military market many would also have had roots further afield. ${ }^{36}$ Some were Muslim and probably most were Hindu, many low caste and Dalit; commanding ranks comprised both Muslim and Hindu men. ${ }^{37}$

Once British commanders were in the Philippines with sepoys, they articulated why these troops were, they thought, particularly useful in this case: "they are [...] formidable to the [local] Indians, who hold moors in the highest Detestation". ${ }^{8}$ Some but not all of the sepoys were Muslim, so the British perception that the locals "[held] moors in the highest Detestation" might reflect locals' conflation of sepoy with "moro" [Muslim], or British generalization. The statement probably reflected panic in coastal Christian settlements that were sometimes raided by seafaring Muslim groups of the Sultanate of Sulu, whose captives became part of the Indies' slave trade. But the comment also reflects a British effort to capitalize on these military laborers of empire through how they arranged types of people in relation to each other. Sepoys' labor was more valuable when transported to the Philippines because of locals' ideas about "moors".

An additional forty-three to sixty of the land forces on the Manila expedition were "irregulars" on loan from the Nawab of Arcot, who, other than a few European officers, were "Topasses" in the parlance of the Company's military. ${ }^{39}$ Topasses were South Asian Indo-Portuguese Catholics, a capacious category (see Chakraborty, in this Special Issue). Many of these

34. Daniel Baugh, The Global Seven Years War, $1754-1763$ (Harlow, 201 I), p. 465.

35. They were offered and insisted on the same batta rate as had been paid on that expedition; see Manilha Consultations, II, p. Is.

36. On sepoys' families in Madras: Manilha Consultations, I, pp. 33, 60; Manilha Consultations, II, p. 2 I; Manilha Consultations, V, pp. 2-3. On military markets and mobility: Kolff, Naukar, Rajput and Sepoy, and Welsch, "Sons of Mars".

37. From W.K. Elles's characterization of W.J. Wilson's notes about rare surviving sepoy nominal rolls of those who eventually returned from the expedition, in [Office of the Adjutant General], Precis of the Services of the Madras Native Army, with a Note on its Composition (Ootacamund, I886), app. II.

38. BL: IOR/P/25I/49, bk. I, p. 83 .

39. "Nabob's irregulars" BL: IOR H/77, pp. 48-49; Manilha Consultations, I, p. 4, enumerates somewhat higher numbers. Other than the highest-ranking officers, these men were probably all topasses, since some are referred to as such in $\mathrm{BL}: \mathrm{IOR} / \mathrm{P} / 25 \mathrm{I} / 5 \mathrm{IA} \mathrm{bk} .3$, p. 42 . 
Indo-Portuguese in South Asia had come into the employ of the Dutch and English militaries, as well as militaries of Indian rulers, often serving as gunmen (artillerymen)..$^{40}$ They also served as infantrymen - in their own distinct units - as was the case in this instance. Their status vis-à-vis "European" was ambiguous. In troop returns, they were listed in a table alongside European troops, though in a column separate from them; in contrast, the sepoys were generally counted in a separate table. On this expedition, they were paid the same as "European" troops, but that may not have been the general rule. ${ }^{4 \mathrm{I}}$ The sepoys and topasses on the Manila expedition - rank and file as well as officers - were overseen at their units' highest levels by officers who were European..$^{2}$

As part of the infantry, the Company also contributed seventy-four "Coffreys", men from sub-Saharan African areas historically sources of Portuguese military and seafaring labor, particularly from the Cape, the Swahili coast, and Madagascar. ${ }^{43}$ In the Company parlance of the Coromandel coast, the term "Coffrey" had gone from designating religious status ("unbeliever", i.e. non-Muslim, a term derived from Arabic but learned by Portuguese from their Swahili allies and rivals) to having a racial meaning. ${ }^{44}$ As one Englishman explained in $176 \mathrm{I}$ with reference to the Carnatic Wars, "Coffrees, (By the French called Cafres) is now become the general name for all negroes who are brought to India from the Cape, the coast of

40. Marshall, "Western Arms in Maritime Asia", pp. 25-26; Pradeep Barua, "Military Developments in India, 1750-1850", The Journal of Military History, 58:4 (1994), pp. 599-616, 602; Channa Wickremesekera, "Best Black Troops in the World": British Perceptions and the Making of the Sepoy I746-I80s (New Delhi, 2002), pp. 86-87. For some contemporary references, see Richard Owen Cambridge, An Account of the War in India between the English and French, on the Coast of Coromandel, From the Year 1750 to the Year 1760 (London, 176I); and Henry Davidson Love, Vestiges of Old Madras, 1640-I800, 4 vols (1913), II, pp. 82, 196, 295, 352 .

4I. Those on the Manila expedition were accustomed to being paid "as Europeans" at the rate of two pagodas and twenty-one fanams per month (Manilha Consultations, I, pp. 2, 4), equivalent to European infantry rates, and quite a bit more than the sepoy rate (Orders, Rules and Regulations, pp. 9, 2I); as this was an exception, they were likely not generally so well paid.

42. BL: IOR H/77, pp. 48-49; Manilha Consultations, I, p. 4.

43. BL: IOR H/77, pp. $4^{8-49}$ (the main table indicates fifty-four, but a note below it records that twenty additional "coffereys" were embarked). On Portuguese labor, see Shihan de Silva Jayasuriya, "Identifying Africans in Asia: What's in a Name?", African and Asian Studies, 5:3-4 (2006), pp. 275-303, 286. It is unclear whether "Coffreys" of Madras might also have included those with roots in Africa's Horn, historically a source for military labor in western India. See idem, African Identity in Asia: Cultural Effects of Forced Migration (Princeton, NJ, 2008), ch. 4; Richard Pankhurst, "The Ethiopian Diaspora to India: The Role of Habshis and Sidis from Medieval Times to the End of the Eighteenth Century", in Shihan de Silva Jayasuriya and Richard Pankhurst (eds), The African Diaspora in the Indian Ocean (Trenton, NJ, 2003), pp. I89-221.

44. Jeremy Prestholdt, "Portuguese Conceptual Categories and the 'Other' Encounter on the Swahili Coast”, Journal of Asian E African Studies, 36:4 (200I), pp. 383-406, 386, 390. 
Guinea, or any other parts of Africa, and chiefly from Madagascar: they are brave and steady in the field", a characterization that reflects their importance as military laborers. ${ }^{45}$ In the Company's Madras military of this period, "Coffrey" companies listed in infantry rolls are segregated from sepoys, and appear alongside but distinct from Europeans and topasses. ${ }^{46}$ "Coffreys" from Madagascar also worked, enslaved, at the Company's plantations in Bencoolen, Sumatra. ${ }^{47}$ According to Wickremesekera, military "Coffreys" were enslaved; at least during the British occupation, however, they were paid..$^{4}$

Filling out the ranks of the Company's infantry were two companies (totaling 165 rank and file) of French deserters, about which we have already heard. ${ }^{49}$ The only rank and file with English origins were 57I royal infantrymen, those whom the Company was most anxious to have returned to Madras as soon as possible, and probably the Royal Artillery's 57 gunners and matrosses (gunner's assistants). Less clear are the origins of the Company's 29 artillerymen and 7I "Pioneer" infantrymen (categorized with Europeans)..$^{50}$

Somewhere amongst these British military personnel who set foot on Philippine soil were a good number of men referred to in other records as "lascars", though it is unclear from the sources in which of the above categories, if any, they may have been counted. This term is even more slippery than the other somewhat arbitrary categories through which the company understood its military labor. ${ }^{5}$ East India Company officials referred to non-European laborers who manned the company's ships as "lascars", but also described as lascars men who performed menial labor in company encampments, including "gun lascars", who worked as part of the artillery hauling equipment. ${ }^{52}$ Lascars laboring for the Company in encampments and as part of the artillery may have been distinct from most of the seafaring

45. Cambridge, An Account of the War in India, unnumbered page of the Glossary preceding the Introduction.

46. For example, BL: IOR/L/MIL/I I/ıо9.

47. BL: IOR/E/4/30I.

48. Wickremesekera, "Best Black Troops", p. 91; BL: IOR/P/25I/53, p. 1080.

49. BL: IOR H/77, pp. 48-49. In that document, Pioneers are listed with the Company's other non-sepoy troops. Later, the Manila board refers to "Europeans including the Pioneers" (Manilha Consultations, V, p. 8).

50. BL: IOR H/77, pp. 48-49. Overall, these numbers of land forces correspond neatly to the numbers given as landed in "Draught of the Great Bay of Manilla and Harbour of Cavita". That data may have the same source.

51. Aaron Jaffer, Lascars and Indian Ocean Seafaring, 1780-1860: Shipboard Life, Unrest and Mutiny (Rochester, NY, 2015), Introduction.

52. BL: IOR/P/25I/48-49. Wilson, History of the Madras Army, I, and the 1766 regulations refer to the categories of "European Infantry", "Sepoys", "Artillery", and "Lascars", consistent with the relationships being analogous such that European infantry is to sepoy as European artillery is to lascar. 
lascars, whose skills would have been more specialized, but some of the gun lascars may also have been seafarers grounded between sailing seasons. ${ }^{53}$

In the end it is unclear how many lascars were part of the expedition, and how they were enumerated amongst the personnel captured in the sources treated above, but their number was significant. Just a couple of weeks before the whole embarked from Madras, Company officials were planning for a force of 350 lascars (with eighteen lascar officers). ${ }^{54} \mathrm{~A}$ few months into the occupation, more than 200 must have been present, because the Manila board suggested sending that number on an expedition to the countryside. ${ }^{55}$ Lascars in the Manila occupation performed grueling manual labor - digging, clearing, constructing fortifications, and hauling guns and ammunition. ${ }^{56}$ As part of the artillery, lascars on the expedition were paid more than sepoys, though, consistent with general practice in the Madras military at the time, probably only about a third as much as the lowest-ranking European artilleryman. ${ }^{57}$ Most of these lascars probably hailed from around Madras, as Company officials there, worrying that they would not be able to recruit enough of them, offered advance pay to them that they could leave with their families before departing - the same offer they made to sepoys. ${ }^{58}$ As with the sepoys, many were likely veterans of the expedition to Bengal. ${ }^{59}$ Some of these lascars had seafaring skills. ${ }^{60}$

Finally, these British forces brought from India were supplemented in the Philippines with Chinese laborers, referred to by the British usually as "Chinese coolies", "coolies", or "coolie lascars", reflecting the fact that they were employed in much the same way as the lascars from Madras: hauling gun carts and other heavy loads, or performing other demanding physical labor, and indeed they are often mentioned in the same breath. ${ }^{6 \mathrm{I}}$ The coolies were paid, though officials were clear that they were not to be put on the same terms as other Company military personnel. The British had counted

53. Janet J. Ewald, "Crossers of the Sea: Slaves, Freedmen, and Other Migrants in the Northwestern Indian Ocean, c.1750-1914”, American Historical Review, I05: I (2000), pp. 69-9I, 73 .

54. IOR/P/25I/48 bk. 2, p. I 20.

55. Manilha Consultations, V, p. 8.

56. Hauling military equipment: Manilha Consultations, II, pp. 4, I4.

57. Part of artillery: Manilha Consultations, VI, p. i i8; Pay: Manilha Consultations, V, p. 65. Orders, Rules, and Regulations, pp. 7, 9, 21, 38.

58. Some seafaring lascars were likely to have been Muslim and spoke Tamil. George Dodwell, $A$ Narrative of the Principal Transactions betwixt the Agents, and Officers of the Hon. East India Company, and George Dodwell, Esq. Commander of the Ship Patty [...] (London, 1773), pp. $7 \mathrm{I}-83$.

59. Lascars (like sepoys) complained that they had been promised the same pay and batta as the Bengal expedition (Manilha Consultations, VI, p. I 2).

60. BL: IOR/P/25I/5IA bk. 2, p. 46r.

61. Manilha Consultations, I, p. 60; Manilha Consultations, II, pp. 4, 6-8, 9, II; Manilha Consultations, VI, pp. 67, 71, I06, i is. 
on Manila's Chinese welcoming them with open arms, in light of the regular and brutal expulsions that the Chinese suffered from Manila's Spanish authorities. It is not possible to give a full account here of the various ways that Chinese skills and labor were central to British dreams for the occupation, but we will see one part of it in this military labor.

The British envisioned, organized, and disciplined their military force through these categories. It is sometimes difficult to see past the British imagination to how the people who were interpolated in these categories saw their own affinities and affiliations. The categories - as well as the difficulty of pinning down their contents - reveal the motley nature of the crew, and the broad reach of forces that produced these people as British military labor en route from Madras to Manila in late 1762 . As we will see when we follow them to Manila, the ties that bound them to their commanders were tenuous, and sometimes broke.

\section{TROUBLE IN MANILA}

The British occupation of Manila lasted from September 1762 until April $1764 .^{62}$ When British forces first arrived, they were challenged by Spanish forces (a mix of soldiers from New Spain, probably mestizos and criollos, and people native to central Luzon), but the British took Manila proper more easily than they had anticipated they would. The Spanish were caught unprepared. Manila was awaiting a new Governor General from Spain, and the acting Governor General was Archbishop Rojo, who had no military training. Furthermore, Rojo had not yet received word from Spain that they were at war with the British.

Spanish forces quickly capitulated to the British, agreeing to accept British sovereignty in Manila, and also agreeing that the city would pay a significant ransom in return for its citizens being spared from further looting of their property - looting that had begun when British troops breached the walls of the city. ${ }^{63}$ Although the British were technically in control, outside of Manila, a high-ranking Spanish official, Simon de Anda, led a growing military resistance of Spanish military and locals. The British may not even have cared about the situation outside of Manila except that the city depended on the surrounding areas for food, and also the British sought word of the galleon's arrival from Acapulco, hoping to seize its silver to fund, along with the ransom money, the upcoming season's investments in Canton. This very abbreviated account of early events sets the stage on which we can see 
how British commanders experienced significant problems controlling their military labor.

De Anda's resistance early on posed military and labor challenges for British officials. "The great extent of the Place \& present situation of affairs in the country", the board reported soon after the capitulation of Manila, "have induced the General to leave all the Troops that came upon the Expedition" rather than sending many of them back, as had been planned. Even with all the troops staying, they were "but barely sufficient for our Garrisons" and so the board "intend[ed] applying to the Presidency [Madras] for reinforcements of seapoys by all opportunities", "thought by the General to be absolutely necessary". ${ }^{64}$ General Draper's words were a bit spicier. Though he praised the royal infantrymen, he lamented that he could not send any of them back because "We have no Troops besides who can be Depended upon". ${ }^{65}$ Amongst those least trustworthy, according to Draper, were the French deserters.

Indeed, almost immediately, the French deserters began deserting. ${ }^{66}$ In late December, Manila company officials wrote that "We have the Mortification to inform you that no fewer than twenty Men have deserted" and that "all of them to a Man wou'd have certainly have gone off" had they kept using them for patrols and detachments, because de Anda had sent "Numbers of Emmissaries to entice them particularly, as they are Catholicks". ${ }^{67}$ Friars supporting de Anda indeed sought to encourage French deserters to join the Catholic side of the conflict; some friars offered only a "prevaricating defence" when confronted with letters showing that they had been "encouraging the Desertion of our [the Company's] People". ${ }^{68}$ The losses were significant enough that the Manila board asked commanders to pardon deserters who voluntarily surrendered themselves. ${ }^{69}$

By February, the desertions of the French deserters had reached a crescendo such that Company commanders decided they were more useful to the occupation if they were shipped back to Madras. Since they had "deserted in great numbers" to de Anda's side, one wrote, "least [sic] the rest shou'd follow which I have great reason to apprehend we have been obliged to petition the Admiral to take them off the Island". ${ }^{70}$ In early March, the Manila council, explaining why "the frequent Desertions from the French Companies have put us to the disagreeable necessity of sending them to

64. Manilha Consultations, III, p. 3.

65. TNA: WO/I/I39, p. 4I I (Cushner, Documents Illustrating the British Conquest of Manila, p. I47).

66. TNA: $\mathrm{WO}$ i/ı 39, p. 445 .

67. BL: IOR/P/25I/49 bk. I, pp. $83-84$.

68. Manilha Consultations, V, p. 72.

69. Manilha Consultations, II, p. I2; Manilha Consultations, V, p. I I.

70. TNA: WO I/r 39 , p. 445 . 
the Coast [of Coromandel]", blamed Catholics and Catholicism: "to have continued them here might have been attended with very bad Consequences, as they are most of the Romish Religion, the Fryars would by degrees have carried off the whole". ${ }^{1 \mathrm{I}}$ The Admiral's assessment was characteristically more cutting. Responding to the Company's request that he ship them back, he wrote, "I learn with more concern than surprize the Considerable Desertion which has happened in the Company's Troops", and pointedly reminded the Company that it had only itself to blame: "with regard to the French Company's [desertion] I shall say the less as my opinion was well known to the Council of Madras before they Embarked". ${ }^{72}$ He ultimately granted their request in terms that emphasized his benevolence and generosity, and suggested the incompetence of those who had overridden his objections: "If you judge the safety of the Garrison to depend on sending them away I will receive them on board his Majesty's ships[. B]ut [...] I am on guard against them as Enemies". ${ }^{73}$

It was in part because of early problems with the French deserters that, by December, officials in Manila were urgently requesting that reinforcements to the tune of 2,000 more sepoys be sent from India, as well as more armed vessels. ${ }^{74}$ Sepoys were both particularly valued by Company officials, but also the source of challenges. It will be recalled that British commanders worried about sepoy and lascar discontent before the troops even left Madras. In order to persuade sepoys and lascars to go on the expedition, the Company offered them two months' advance pay - which most left with their families - and the option of having any part of their pay at Manila disbursed directly to their families in Madras..$^{75}$ This benefit caused problems. By mid-November, the Manila council noted that since they "had left the greatest part of the pay advanced them at Madras with their families there" they had been "reduced [...] to great hardships since their arrival here" recall that sepoys had to provision themselves from their pay - and so they were to be advanced one additional month's pay out of their prize money. ${ }^{76}$

If many sepoys arrived in Manila with nothing, and could not expect pay until December, that might go some way toward explaining why they were blamed for the looting that took place during the early days of the siege. British commanders tended to minimize the plunder their troops had committed during the early days of the siege of Manila, though what they admitted, they blamed on the motley crew, a "Variety and Confusion of People,

7I. Manilha Consultations, III, p. 37.

72. Manilha Consultations, V, pp. 67-68.

73. Ibid.

74. Manilha Consultations, III, p. I2; BL: IOR/P/25 I/49, bk. I, p. 77.

75. Manilha Consultations, I, p. 60.

76. Ibid., p. 33 . 
who differed as much in Sentiments and Language, as in Dress and Complexion", who were not easily restrained. ${ }^{77}$ Sepoys were convenient scapegoats, to be sure. But likely, too, the sepoys who entered the battle for Manila without prospects for the means to sustain themselves for over a month may have sought those means in what they could seize during the battle. It helps to consider how these men might have encountered or participated in plunder elsewhere. Plunder was widely used in the Carnatic Wars, on all sides, sometimes clearly according to commanders' orders, and other times supposedly the unsanctioned actions of unruly troops. ${ }^{78}$ Plunder was an established form of military pay, and so while it was only sometimes officially sanctioned, at other times it would likely have been unofficially tolerated as a way to effectively supplement troops' pay. It may be, then, that the officers of the Manila assault encouraged their troops to plunder, despite their protestations otherwise and their condemnation of what they characterized as errant actions of unruly sepoys. Troops may also, however, have plundered in insubordination and in defiance of their commanders, as a form of direct action to ensure their pay.

Early on in the occupation, British commanders tried to take steps to ameliorate sepoys' discontent, appealing again to sepoys' desires to support their families: they offered that sepoys might opt to send their pay or a portion of it back to their families with the first Madras-bound ship, rather than receiving it in Manila. ${ }^{79}$ It quickly became clear, however, that sepoy discontent was a significant strategic problem. One of the bones of contention was around batta, the per diem allowance from which sepoys were accustomed to provision themselves while in the field. In early December, the sepoys were "disappointed" and "much dissatisfied, at not receiving Batta at the rate allowed upon the Bengal Expedition, which they alledge was promised them before embarking at Madras". ${ }^{\circ}$ The sepoys agitated around this issue, "appealing to Captain Flint their Commandant" who confirmed their account; the board decided in their favor, noting the principle that "they are justly entitled to every reasonable Indulgence, in those distant parts". ${ }^{8}$ But practical matters were at least as pressing, for the board described their decision as "Politic", both "to pacify" the sepoys as well as "to facilitate [...] encouraging others to come here". ${ }^{82}$ Indeed, "every cause of disgust ought to be avoided if possible, otherwise the [Madras]

77. William Draper, Colonel Draper's Answer to the Spanish Arguments [...] (London, 1764), p. $2 \mathrm{I}$.

78. See, for example, Cambridge, An Account of the War in India, p. I32; Baugh, Global Seven Years War, pp. 465, 466.

79. Manilha Consultations, V, p. 2.

80. BL: IOR/P/25 I/49, bk. I, p. 83; Manilha Consultations, II, p. I 5.

8. Manilha Consultations, II, p. Is.

82. BL: IOR/P/25I/49, bk. I, p. 83 . 
Presidency may find it a difficult matter to send us the reinforcements of this useful Corps that are necessary" ${ }^{83}$ Sepoy discontentment only increased. In March, when the Admiral wrote to the council agreeing to relieve them of the problem of the remaining French deserters, he added:

the Desertion of Sepoys is an event you may perhaps account for better than I, I have observed they have served here with great dissatisfaction and frequently complained the Engagements they entered into at Madras were not made good to them, if this is the case, the remedy is in your [East India Company officials'] own hands. ${ }^{84}$

The French and sepoys were not the only problems. British commanders of the Manila garrison warned the board in March that "the desertion of the Soldiers, Seapoys and lascars has been very great", and British records from the Manila operation are replete with accounts of their own forces deserting French, "European" (likely also the French), sepoys, and lascars - as well as with reports of those deserters fighting with enemy forces. ${ }^{85}$ Pay was thought to be an issue in all cases, and the British commanders inconsistently tried to remedy discontent about pay. In late January 1763 , one of the British commanders reported from the field that he planned to try to lure back the French deserters to the British side by offering them "Pardon with a Bounty". ${ }^{86}$ Lascars complained that they were promised the same pay and batta as on the Bengal Expedition, but instead "are paid 8 Fanams less than at Madras", and so the Board agreed to make up the difference. ${ }^{87}$ Yet, these steps did not have the desired effect. In March, commanders of the Manila garrison warned that the "clamours [of the soldiers, sepoys, and lascars] on account of their Pay being so small grow stronger dayly", and so recommended that "an augmentation be made to their subsistence which considering the excessive Prices of the necessaries of Life is really much too small as may enable them to support themselves with Comfort and put a stop to their desertion". ${ }^{88}$ In response, the Manila board ordered that "the Military \&ca [presumably European troops] be daily allowed 2 Drams" of alcohol - apparently hoping that increased rations of booze would be sufficient to stem their discontent - and that "the Sepoys and Lascars [be allowed] I Dollar Pr. Month Gratuity" ${ }^{89}$ These small steps were not enough to effectively combat desertion.

The issues of pay and food were connected ones, not just for the military personnel in the Manila garrison, but for commanders as they planned efforts

83. Manilha Consultations, II, p. Is.

84. Manilha Consultations, V, pp. 67-68.

85. Ibid., p. 70; see also pp. 72, 107, 108.

86. Ibid., p. 27.

87. Manilha Consultations, VI, p. I2.

88. Manilha Consultations, V, p. 70.

89. Ibid., p. 71. 
to get at the root of both problems. They sent parties into the countryside to secure food, and also in search of the silver supposed to be arriving in the galleon from Acapulco. They worried that should the galleon's silver reach de Anda first, he would even more effectively woo deserters from British forces. In fact, that seems to be exactly what happened. The commanders of the Manila garrison reported in March that their intelligence told them that British soldiers were being offered by de Anda's agents one hundred dollars up front, and a dollar a day, to desert. ${ }^{\circ}$ The material rewards promised by de Anda's agents - or perhaps even the rumor of them - might have spoken volumes to these men, aggrieved as they were over pay. Though the Manila board approved only paltry pay increases, they offered a two-hundred-dollar reward for helping to convict those who were recruiting British forces to join the Spanish resistance, planned to hire one hundred Chinese to patrol the bridges over which garrison deserters had to pass, authorized a thirty-dollar reward for catching a deserter, and banned the use of covered litters, in which soldiers were thought to escape the city. ${ }^{9 \mathrm{I}}$ While many deserted from the field or while on detachment, these measures show that some soldiers deserted from their garrison within the walled city of Manila itself; the bridges that connected it to its suburbs, and the covered litters in which its wealthier residents would themselves travel, were routes by which garrison soldiers could escape the more easily surveilled interior of the walled city into the more populous suburbs which housed so many of the city's markets, its commerce, and many other laborers.

The situation only deteriorated: a year into the occupation, the Governor of Madras wrote to London that "We have reason to believe the Troops we sent to Manilha, are greatly reduced by death and desertion, if we receive one half of the number sent it will exceed our expectation". ${ }^{92}$ Several months later, they received word that "Our Troops were reduced by Death \& desertion to about 400 Europeans \& as many Seapoys", and that "upwards of ro० of Our Deserters" were fighting for de Anda. ${ }^{3}$

Members of the sea forces were troublesome, too, when they were on Philippine soil. One of the commanders of an expedition around Laguna de Bay, in search of food and the galleon's silver, expressed "great Mortification and sorrow that the Sailors [who were on patrol in the large lake] have plundered some of the Houses in the Village" and deplored "the actions of those Villians", as they undid his careful work to win over locals' cooperation. ${ }^{94}$ For this reason, he preferred to take on patrol lascars

92. BL: IOR/E/4 300, pp. 212-213; abstracted in Henry Dodwell, Calendar of the Madras Despatches I754-I765 (Madras, 1930), p. 344 .

93. BL: IOR/P/25I/5IA bk. I, pp. 203-204.

94. Manilha Consultations, II, p. I I. 
and Chinese coolies, whom he trusted better. The same commander praised both the coolies and the lascars on his expedition as having "behaved like Angels", and noted that the lascars in particular had "done more in the working way than ever the same number of Men did in the time", despite enduring extreme hardship. ${ }^{95}$ Because they had behaved so well, he "found it necessary to be liberal" with some of them on account of their hard work under dire conditions. ${ }^{96}$

In the reports of this expedition, we can see some of the ways that the categories of British labor were enacted, and other ways that they were flexible. Though the expedition had lascars and coolies, the Pioneers (categorized as European) were not exempt from particularly onerous physical labor: they worked alongside lascars clearing particularly thick bamboo in order to construct an esplanade around a church that had been captured. ${ }^{97}$ In another mark of the ways these categories might have some flexibility, the commander at one point described himself as having been "obliged to convert" a number of the royal infantrymen on the expedition "into Lascars, by rewards and fair speeches", as he did not have enough lascars to haul the artillery equipment. ${ }^{98}$ Another example of flexible use of labor, and labor's categories, was when the Company decided that since the "Lascars are willing to act as Sepoys", they would be "tought twice a Week to load and Fire". This change in work had to be carefully categorized, however, to avoid grumbling over pay:

to prevent the Sepoys from murmuring which if they were put on an equal Footing they would not fail to do, as they receive less Pay than the Lascars Agreed that they (lascars) be called the Artillery Volunteers that they nevertheless continue in their former employment under the Engineer and Military Storekeeper. ${ }^{99}$

In other respects, however, these categories of labor could not be bridged: the same commander wrote that: "The Chinese are good Cooleys, but I have had inexpressible Trouble for want of some one among them invested with authority [so] it would still be of great use if you could get me such a person", and the Manila council agreed to send such. ${ }^{100}$ While the Chinese coolies had some agency in determining their pay, the Manila council was determined to keep expenses down and to retain rigid boundaries between the terms of coolies' labor and the other Company employees: the paymaster of the expedition was instructed that "the Custom of Batty should by no

95. Manilha Consultations, II, pp. 6, 8; see also pp. 4, I I, I4, I7, 50; Manilha Consultations, V, p. 8; Manilha Consultations, VI, p. I 2.

96. Manilha Consultations, II, pp. 4-6, 8 .

97. Ibid., p. 10.

98. Ibid., p. 17.

99. Manilha Consultations, V, p. 65.

ı००. Manilha Consultations, II, pp. 8-9. 
means be introduced" for the Chinese coolies. He could offer them one-half real more than what was paid in garrison, and even one full real if they refused to accept just one-half, but the board reminded the paymaster that "we rely on your Endeavours to settle it in the cheapest manner possible". ${ }^{\text {Ior }}$

Finally, on the question of troublesome or cooperative labor, we might note that by the end of this most vexed occupation, the remaining board members at Manila reported back to Company officials in Madras that "As the Coffres in the Companys Service have behaved remarkably well during the Expedition, and the times have been very hard on their earnest representation we granted to them the same pay as the Nabob's Irregulars". ${ }^{102}$ It may be remembered that the "Nabob's irregulars", Indo-Portuguese, had been granted pay "as Europeans" in the way that they were accustomed to being paid by the Nawab. ${ }^{103}$ These African soldiers, then, persuaded the board to grant them pay "as Europeans".

\section{CONCLUSION}

While all of these laborers of the British occupation were paid, the conditions under which these men labored - even the most valued members of the Royal 79 th - could hardly be said to be of their own choosing. Way describes how even the formally free labor that comprised most of the British army in America during the Seven Years War had many qualities that made it closer to other forms of contract labor in which the terms of employment are highly coercive and conscripted, such as indenture: even "freely" recruited military laborers enlisted for long stretches of employment, lived with their employers, and were not part of independent households. ${ }^{\circ}{ }^{\circ}$ In these respects, we find much of the same coercion in the experiences of these other British troops in another theater of that war.

Many, though, opted out. Weighing the likely risks and opportunities of remaining under their British commanders against those of leaving to pursue their livelihood by other means, they deserted, as many would have already done in India. These deserters likely brought with them from Madras the expectation that, as in India, deserters in Manila and its environs could expect to be welcomed by "enemy" forces, as indeed many were. When food was short and pay not forthcoming as promised from their British commanders, they set their sights on the other side - with easier access to food, and of whose silver they would have heard. Yet deserting in the Philippines must also have seemed a different proposition from deserting in India, for 
Manila and its environs were for nearly all utterly unfamiliar in landscape and languages. And aside from this exceptional moment when two different employers competed for military labor, it had no military labor market to speak of. If one came from France, or Scotland, or India's Coromandel coast, it must have seemed a great risk to leave the ranks of those who would at least in principle go back to Madras at the end of the conflict, and instead opt to join an army of Mexicans, Kapampangans, Tagalogs, and a few Spaniards. For some, Catholicism would have made the otherwise foreign life more familiar. Also, deserters may have thought that from the port city of Manila they could find their way on some ship to Canton and from there back to India or Europe. Those with seafaring skills could have easily done so, for there was always a market for seafaring labor in Manila.

We also see in this Indian Ocean story a strikingly complicated combination of highly differentiated categories of labor, somewhat haphazardly combined. The categories of labor that were part of this expedition reveal something about how the Company thought of the people whose labor it might coerce, if little about how those people thought of themselves. The formation of these categories, and the ways they composed this expedition, were utterly inseparable from financial prospects for the East India Company. The Company functioned by composing complex assemblages of labor, drawn from near and far, allies and enemies. Company officials in Madras believed that they could most safely afford to spare from Madras those who were sepoys, lascars, "Coffreys", and the Nawab's topasses, but they sought to keep in Madras as many royal and European troops as possible, with the significant exception of French deserters, who they were eager to send away. These exigencies of the Company - concerned as it was about the security of its Coromandel and Bengal ports, and eager to capitalize on its support for the Nawab of Arcot - conflicted with the expedition's more narrowly military focus as the commanders of royal forces understood it.

What might be more surprising is that even those at the bottom of the hierarchies of labor might, under the extraordinary circumstances of the occupation of Manila, be able to push for better pay. The flexibility that commanders sometimes showed, in terms of pay and in pardoning deserters, attests to the challenges the East India Company faced when it moved from Madras to Manila. As in the South Asian context, its troops had ample opportunity to desert, but, unlike in South Asia, in Manila the Company could not recruit from enemies' deserters or draw on allied rulers' forces. Instead, its only local sources of new military labor were local Chinese. The challenges of the British in Manila show in part that when cut off from South Asian military markets, those trying to command forces had fewer options, whereas their troops still found the opportunity to desert. These British commanders, then, generally could not enforce the corporal and capital punishment that disobedience and desertion typically merited 
in the Atlantic context, though there, too, we see leniency when an army depleted by desertion had few prospects for fresh recruits. ${ }^{\text {IOS }}$

The labor of both British and Spanish colonies changed substantially after the British occupation. In British India, systems of sepoy recruitment, pay, and discipline became much more standardized and bureaucratic, and the British focused on producing opium to trade with Canton rather than trying to trade its other manufactures for the sea and forest products of the Indies Seas. In the Spanish Philippines, the city of Manila and the surrounding countryside were transformed by the introduction of the tobacco monopoly, the first significant Spanish effort to manufacture in the colony, and the tribute system was overhauled to raise more revenue: in short, the colony was to be made profitable. ${ }^{\text {I06 }}$

The British occupation of Manila is an exceptional moment, but in tracing its labor we see interconnections of the wider Indian Ocean world and the Philippines as part of it - interconnections that form a web of human labor and struggle, commercial aspirations, and material goods. This story, unfolding as older forms of empire were fading but newer ones were just emerging, shows new commerce emerging as an uncertain, sometimes improvised, sprawling network of trade, diplomacy, and military force.

I05. Ibid.; Brandon, “The Privilege of Using Their Legs”, p. 83.

106. Ed. C. de Jesus, The Tobacco Monopoly in the Philippines: Bureancratic Enterprise and Social Change, I766-I880 (Quezon City, I980); Newson, Conquest and Pestilence, p. I30. 